\title{
Trends of poisoning in Central India, Indore Region (Madhya Pradesh)
}

\author{
Pankaj Verma ${ }^{1, *}$, Priya M Misar², Pooja M Missar ${ }^{3}$ \\ ${ }^{\mathbf{1}}$ Assistant Professor, ${ }^{2}$ Post Graduate $1{ }^{\text {st }}$ Year, ${ }^{3}$ Senior Lecturer, ${ }^{1}$ Dept. of Forensic Medicine \& Toxicology, ${ }^{3}$ Dept. of \\ Conservative Dentistry \& Endodontics, ${ }^{1,3}$ SMBT Institute of Medical Science and Research Centre, Nashik, Maharashtra, ${ }^{2}$ Dept. \\ of Obstetrics and Gynaecology, Seth G.S Medical College, KEM Hospital Parel, Mumbai, Maharashtra, India
}

*Corresponding Author:

Email: dr.pankajfmt@gmail.com

\begin{abstract}
Introduction: In this modern civilization, acute poisoning is one of the leading causes of morbidity and mortality and really becoming a burden for our community. Trends of poisoning are increasing as well as changing day by day due to the introduction of more and more chemicals. This study has been taken to understand the trends of poisoning and will be used to plan how to provide healthcare facility and educate the people. Only those cases that came to the Emergency Department and Mortuary with a history of acute poisoning were included in this study.

Materials and Methods: A total of 120 poisoning cases were included from October 2015 to May 2017. The cases were analyzed on various epidemiological, clinical and investigational and postmortem findings through a pre-designed proforma after taking valid consent from the patients or their relatives. Samples were collected and analyzed in Analytical Toxicology lab.

Result: Out of 120 acute poisoning cases, 75 were males and 45 were females. Maximum numbers of patients fall in 21-30 years age group. Most common poison was Organophosphorus (OPP) followed by Aluminium phosphide (Celphos). The mortality rate as per this present study was $21.67 \%$.

Conclusion: Due to the easy availability of insecticides, pesticides and household poisons; there is more exposure accidently or intentional, which creates a huge burden on hospitals. The government, WHO and other organizations have to make strict rules or to ban highly toxic chemicals. Education camps must be organized to train farmers how to use insecticides and pesticides in a proper way.
\end{abstract}

Keywords: Aluminium Phosphide, Analytical toxicology lab, Insecticides, Mortuary, Organophosphorus, Pesticides, Poisoning.

\section{Introduction}

All substances are poisons; there is none that is not a poison. The right dose differentiates a poison from a remedy - Paracelsus. ${ }^{1}$ History of poisoning dates back to before $4500 \mathrm{BC}$. In ancient times in India, poisons were used to destroy enemies and prisoners. Indian surgeon Sushruta defined the various stages of slow poisoning and their treatment with the help of antidotes. $^{2}$ As we are moving towards modern civilization, everything is changing very fast around us. In a similar way, the trends of poisoning also changing from insect and pest killers to various drugs, antidepressants, alcohol and household chemicals. After road traffic accidents, poisoning is holding the second position in unnatural deaths. It was predicted that poisoning deaths by the year 2020 could account for the 10th leading cause of death in the world. ${ }^{3} \mathrm{We}$ are surrounded by so many chemicals that sometimes we are not aware of the toxic exposure of the chemical substances and this mostly happens with farmers or factory workers due to unawareness and knowledge of how to deal with them. In developed countries, drugs are used for intoxication but in developing countries which are agriculture based like India, pesticides and insecticides are the leading trend/cause of poisoning which is highly lethal. ${ }^{4}$ Motto of this study was to enhance the legislative measures by drawing the attention of government and prevent such kind of casualties. With only $1 \%$ of hospitalization, poisoning is the 12th leading cause of admission in pediatric departments in India. ${ }^{5}$ Sometimes it is very difficult to diagnose and treat where there is lack of information about the ingredients present in various products. The type, pattern and cause of poisoning and their end results in a particular region depend on a variety of factors such as their availability, stress of environment and medical care quality. ${ }^{6}$ A small effort has been done through this study to provide some information about acute poisoning in the central region of India.

\section{Materials and Methods}

This is an observational study conducted at Sri Aurobindo Medical College and PGI, Indore during research period $29^{\text {th }}$ of October 2015 to $31^{\text {st }}$ May 2017. Patients came to Department of Emergency with history of poisoning were included in this study. Negative diagnoses for poisoning after laboratory investigations were excluded from this study. Total 120 cases of different poisoning were studied. Patients were examined for the demographic, clinical and investigational profile as well as postmortem findings. History was collected from patients, their relatives, police, first information reports, hospital records and suicide notes if any. Data related to age, sex, religion, community character, education, occupation, socioeconomic status, marital status, type of family, personal habit, mental status/illness and past history, nature/ type of poison, amount consumed, physical state of poison, mode of intake, date and time of consumption of poison and hospitalization, signs and 
symptoms, general condition during admission, blood pressure, pulse, respiratory rate were collected in standardized proforma specially designed for the study and analyzed. Vomit material, gastric lavage contents, blood and urine were collected from each patient as soon as the possible and toxicological analysis was done at Toxicology Laboratory in our Department of Forensic Medicine and Toxicology for further investigation and confirmation of the poison taken. Type of treatment, any antidote, gastric lavage and manner of death was noted. External and internal examination in dead cases was done at Mortuary. Routine viscera and body fluids were sent to Forensic Science Laboratory for chemical analysis. Fig. 1 to 4 showing various instruments used in Analytical Toxicology Laboratory in Department of Forensic Medicine and Toxicology and poisons consumed by patients.

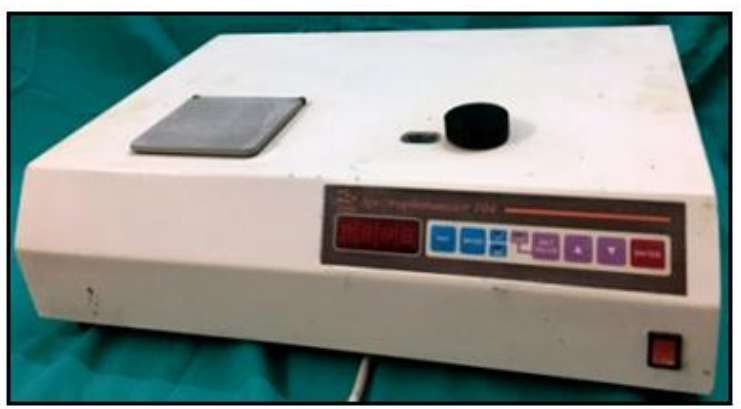

Fig. 1: Spectro-photo meter

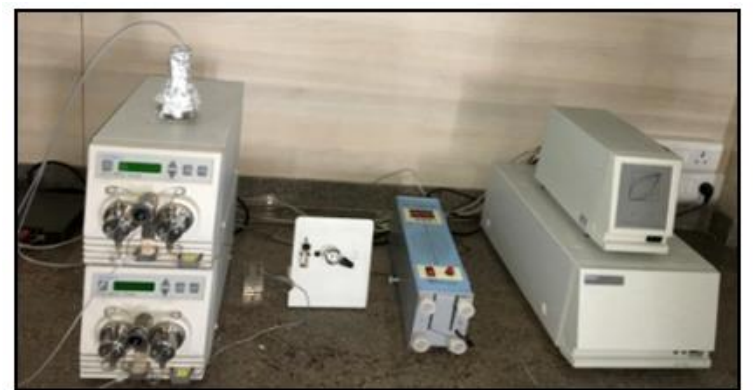

Fig. 2: High performance liquid chromatography (HPLC)

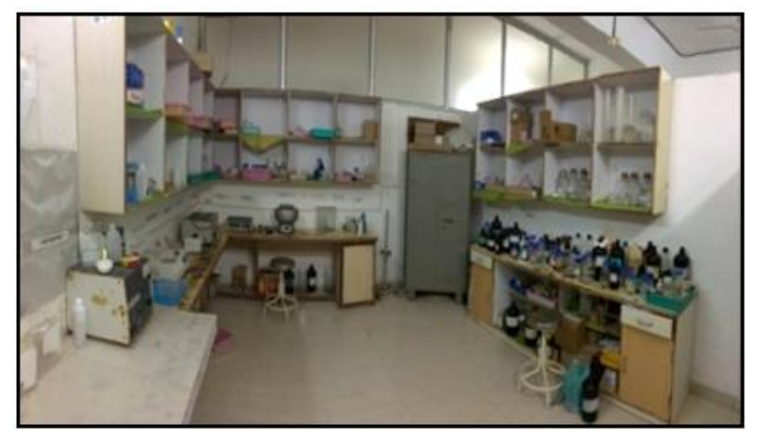

Fig. 3 Analytical toxicology lab

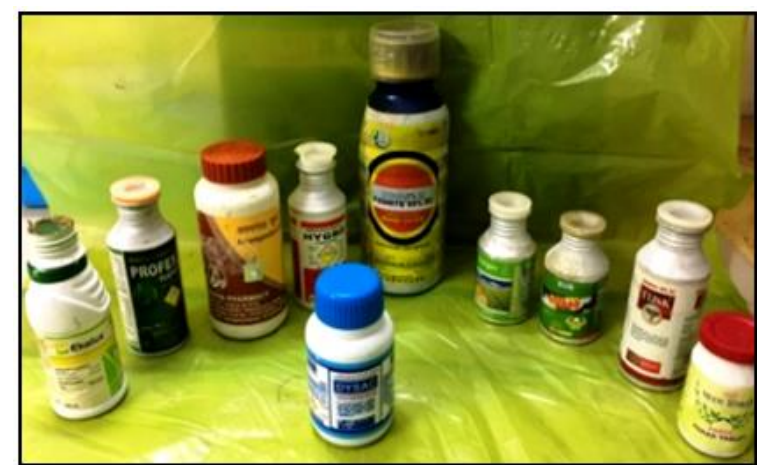

Fig. 4: Various poisons consumed

Result

Out of 120 acute poisoning cases, 75 (62.50\%) were males which shows that males were more prone to poisoning as compared to females 45 (37.50\%). Minimum age of the patient was 1 year and maximum age of the patient was 65 years. Maximum numbers of cases were in the age group of 21-30 years 49 (40.83\%). Most common poisoning was among housewives and un-employed together accounting $43(35.80 \%)$ of cases. Out of 120 cases, $19(15.83 \%)$ of cases were under the influence of alcohol. Most of the patients lived in a joint family i.e. $70 \%$ and belonged to middle or lower socioeconomic status.

Only $8(6.7 \%)$ people had some chronic disease such as hypertension, diabetes, Pulmonary and Kidney disease and cerebrovascular disease. Organophosphate was detected in $41.67 \%$ of cases, Aluminium Phosphide in $20.83 \%$, Zinc Phosphide (Rat killer) in $11.66 \%$ cases. $36 \%$ of victims consumed 21 to $50 \mathrm{ml}$ of Organophosphate, followed by 51 to $100 \mathrm{ml}$ in $28 \%$ of cases. The features indicating poisoning was sudden nausea, vomiting \& epi-gastric burning pain within half an hour of ingestion of poison.

In most of the cases, the first symptoms appeared within $30 \mathrm{~min}$ of administration of poison. Gastric lavage was done in most of the cases. Coconut oil and Soda-bicarbonate was given in all Aluminium phosphide poisonings and Atropine alone or with PAM was used in most of the other pesticide poisonings. $21.67 \%$ of the patients died during treatment and were sent for post-mortem examination.

The mortality rate of Aluminium Phosphide was $32 \%$ and for Organophosphate was $18 \%$. Majority of the poisoning, especially by pesticides were suicidal i.e. $80 \%$ cases, $13.33 \%$ were accidental and $6.67 \%$ were of unknown cause. Homicidal cases were not seen in this study. (Table 1, 2). 
Table 1

\begin{tabular}{|c|c|c|c|}
\hline Sex Wise Distribution & $\begin{array}{c}\text { Males- } 75(\mathbf{6 7 . 5 0 \% )}) \\
\text { Females- } 45(37.50 \%)\end{array}$ & $\begin{array}{l}\text { Age Group } \\
\text { Distribution }\end{array}$ & $\begin{array}{c}1-10 \text { Years- } 2.50 \% \\
11-20 \text { Years- } 19.17 \% \\
\mathbf{2 1 - 3 0} \text { Years- } \mathbf{4 0 . 8 3 \%} \\
31-40 \text { Years- } 22.50 \% \\
41-50 \text { Years- } 7.50 \% \\
51-60 \text { Years- } 6.67 \% \\
>61 \text { Years- } 0.83 \%\end{array}$ \\
\hline $\begin{array}{l}\text { Religion Wise } \\
\text { Distribution }\end{array}$ & $\begin{array}{c}\text { Hindu- } \mathbf{9 6 . 6 7 \%} \\
\text { Muslim- } 2.50 \% \\
\text { Others- } 0.83 \%\end{array}$ & $\begin{array}{c}\text { Area Wise } \\
\text { Distribution }\end{array}$ & $\begin{array}{c}\text { Rural- } 33.33 \% \\
\text { Urban- } \mathbf{6 6 . 6 7 \%}\end{array}$ \\
\hline $\begin{array}{l}\text { Educational Status of } \\
\text { Victims }\end{array}$ & $\begin{array}{c}\text { Illiterate- } 17.49 \% \\
\text { Primary- } 26.67 \% \\
\text { Higher Secondary- } \mathbf{3 0 . 8 3 \%} \\
\text { Graduate- } 23.34 \% \\
\text { Post- Graduate- } 1.67 \% \\
\end{array}$ & $\begin{array}{l}\text { Occupation } \\
\text { Wise } \\
\text { Distribution }\end{array}$ & $\begin{array}{c}\text { Farmers- } 11.66 \% \\
\text { Student- } 15 \% \\
\text { House Wife/ Un-Employed- } \mathbf{3 5 . 8 3 \%} \\
\text { Self- Employed- } 10 \% \\
\text { Serviceman- } 27.50 \%\end{array}$ \\
\hline Marital Status & $\begin{array}{c}\text { Married- } 71.67 \%, \\
\text { M }(42.50 \%), \\
\text { F }(29.17 \%) \\
\text { Un-Married- } 28.33 \%, \\
\text { M }(20 \%), \mathrm{F}(8.33 \%)\end{array}$ & Type of Family & $\begin{array}{c}\text { Joint- 70\% } \\
\text { Nuclear- } 28.33 \% \\
\text { Single- } 1.67 \%\end{array}$ \\
\hline $\begin{array}{l}\text { Socio Economic } \\
\text { Status }^{26}\end{array}$ & $\begin{array}{c}\text { Lower Class- } 10 \% \\
\text { Upper Class- } 19.17 \% \\
\text { Lower Middle- } \mathbf{4 1 . 6 7 \%} \\
\text { Upper Middle- } 25.83 \% \\
\text { Upper Class- } 3.34 \% \\
\end{array}$ & $\begin{array}{l}\text { Pre-Existing } \\
\text { Illness }\end{array}$ & $\begin{array}{c}\text { Diabetes- } 4.16 \% \\
\text { Hypertension- } 1.66 \% \\
\text { Cerebro-Vascular Disease- } 0.83 \% \\
\text { Asthma- } 0.83 \% \\
\text { Kidney Disease- } 0.83 \% \\
\end{array}$ \\
\hline $\begin{array}{l}\text { Physical State of } \\
\text { Poison }\end{array}$ & $\begin{array}{c}\text { Liquid- 59.20\% } \\
\text { Tablet- } 21.67 \% \\
\text { Powder- } 16.67 \% \\
\text { Inhalation- } 1.67 \% \\
\text { Injected- } 0.83 \%\end{array}$ & $\begin{array}{l}\text { Season Wise } \\
\text { Distribution }\end{array}$ & $\begin{array}{c}\text { Summer (March-June)- } \mathbf{4 1 . 6 7 \%} \\
\text { Winter (Nov- Feb.)- } 39.17 \% \\
\text { Rainy (July- Oct.)- } 19.25 \%\end{array}$ \\
\hline $\begin{array}{l}\text { Approximate Quantity } \\
\text { of OPP Consumed }\end{array}$ & $\begin{array}{c}\leq 20 \text { Ml- } 12 \% \\
\mathbf{2 1 - 5 0} \text { Ml- } 36 \% \\
51-100 \text { Ml- } 28 \% \\
\text { Unknown- } 24 \% \\
\end{array}$ & $\begin{array}{l}\text { Time of } \\
\text { Poisoning }\end{array}$ & $\begin{array}{l}6 \text { Am- } 12 \text { Pm- } 27.50 \% \\
12 \text { Pm-6 Pm- } 32.50 \% \\
\text { 6 Pm-12 Am- 37.50\% } \\
12 \text { Am- } 6 \text { Am- } 2.50 \%\end{array}$ \\
\hline
\end{tabular}

Table 2

\begin{tabular}{|c|c|c|c|}
\hline $\begin{array}{l}\text { Month Wise } \\
\text { Distribution }\end{array}$ & $\begin{array}{c}\text { January- } 9.16 \% \\
\text { February- } 7.50 \% \\
\text { March- } 11.67 \% \\
\text { April- } 10 \% \\
\text { May- 16.67\% } \\
\text { June- } 4.17 \% \\
\text { July- } 2.57 \% \\
\text { August- } 7.50 \% \\
\text { September- } 5.84 \% \\
\text { October- } 3.33 \% \\
\text { November- } 11.67 \% \\
\text { December- } 10 \% \\
\end{array}$ & $\begin{array}{c}\text { Week Days of } \\
\text { Consumption of } \\
\text { Poison }\end{array}$ & $\begin{array}{c}\text { Monday- } 15 \% \\
\text { Tuesday- } 10.83 \% \\
\text { Wednesday- } \mathbf{1 9 . 1 7 \%} \\
\text { Thursday- } 11.67 \% \\
\text { Friday-13.34\% } \\
\text { Saturday- } 11.67 \% \\
\text { Sunday- } 18.34 \%\end{array}$ \\
\hline $\begin{array}{l}\text { Time Duration of } \\
\text { Admission After } \\
\text { Consumption of } \\
\text { Poison }\end{array}$ & $\begin{array}{c}<30 \text { Min- } 5.83 \% \\
30 \text { Min- } 1 \text { Hour- } 14.17 \% \\
1-2 \text { Hours- } 29.16 \% \\
\mathbf{2}-\mathbf{6} \text { Hours- } \mathbf{3 4 . 1 6 \%} \\
6-12 \text { Hours- } 6.67 \% \\
12-24 \text { Hours- } 1.67 \% \\
>24 \text { Hours- } 8.34 \% \\
\end{array}$ & $\begin{array}{c}\text { Time Duration of } \\
\text { Appearance of First } \\
\text { Symptom After } \\
\text { Consumption of } \\
\text { Poison }\end{array}$ & $\begin{array}{c}<15 \text { Min- } 40 \% \\
\text { 15-30 Min- } 44.16 \% \\
\text { 30-45 Min- } 6.67 \% \\
>45 \text { Min- } 6.67 \% \\
\text { Unknown- } 2.50 \%\end{array}$ \\
\hline Pain In Abdomen & $\begin{array}{c}\text { Present- 69.16\% } \\
\text { Absent- } 16.67 \% \\
\text { Unknown- } 14.17 \%\end{array}$ & Level of Conscious & $\begin{array}{c}\text { Conscious- 50\% } \\
\text { Semi-Conscious- } 38.33 \% \\
\text { Un-Conscious- } 11.67 \%\end{array}$ \\
\hline Blood Pressure & $\begin{array}{c}\text { Normal- } 30 \% \\
\text { Higher Side- } 24.17 \% \\
\text { Lower Side- } \mathbf{4 3 . 3 3 \%} \\
\text { Not Recordable- } 2.50 \% \\
\end{array}$ & $\begin{array}{l}\text { Alleged Manner of } \\
\text { Poisoning }\end{array}$ & $\begin{array}{c}\text { Suicide/ Attempt To } \\
\text { Suicide- 80\% } \\
\text { Accidental- } 13.33 \% \\
\text { Unknown- } 6.67 \% \\
\end{array}$ \\
\hline Rate of Mortality & $\begin{array}{c}\text { Died- } 21.67 \% \\
\text { Alive- } 78.13 \%\end{array}$ & & \\
\hline
\end{tabular}




\section{Autopsy Findings}

The brain was edematous and congested in $77.78 \%$ of Organophosphorus and $62.50 \%$ of Aluminium Phosphide poisoning cases. $25 \%$ of Aluminium phosphide poisoning cases had petechial haemorrhages over lungs. The inner mucosa of the stomach was hemorrhagic in more than $80 \%$ of cases of pesticides. The liver was yellowish in colour, hard and gritty on the cut in $22.22 \%$ of cases of Organophosphorus. Altered cortico-medullary junction in kidneys was noticed more in Organophosphorus poisoning cases than Aluminium Phosphide poisoning. Fig. 5-6

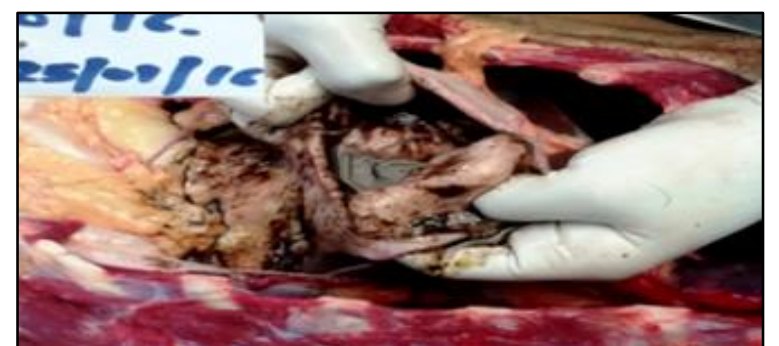

Fig. 5: Stomach contains brownish-black oily fluid, mixed with altered blood with full thickness perforation

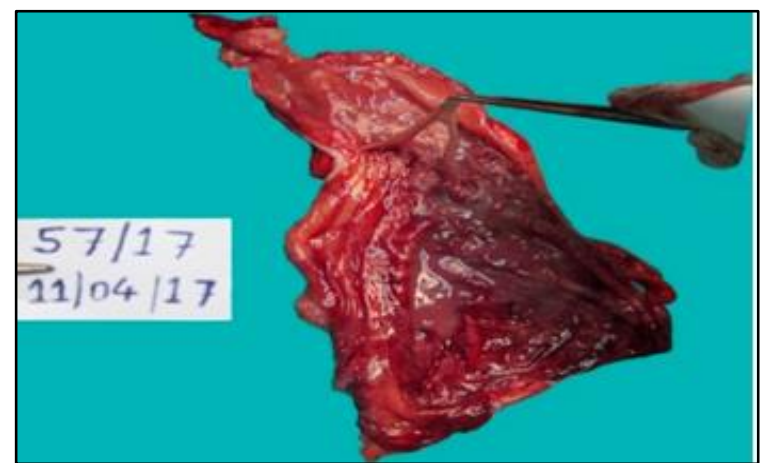

Fig. 6: Sloughed mucosal layer of stomach lifted with forceps

\section{Discussion}

Poisoning is always a burden on the community in terms of money, material and over crowdedness of hospitals. According to a study in India, was found that around $27 \%$ of pesticide poisoning cases require ventilation for varying periods. ${ }^{7}$

In the present study males, $62.50 \%$ outnumbered females $37.50 \%$. Most of the cases were Hindus $96.67 \%$ which is consistent with other studies. Males being the main breadwinner in the family and the burden of earning for livelihood are on them and the male ratio being more than female, are the reasons for the incidence of poisoning more in males. Similar results were observed in various other studies. ${ }^{8-10}$ Similar results were not observed by Naik $\mathrm{SB},{ }^{11}$ Jaychandran $\mathrm{M}^{12}$ and Barman DD. ${ }^{13}$

In the present study most of the cases belong to the age group 21- 30 years $40.83 \%$ followed by age group
31- 40 years $22.50 \%$. This observation is consistent with the other studies. ${ }^{2,3,14}$ Some studies observed different data. ${ }^{11,15,16}$

Organophosphate followed by Aluminium phosphide was the most common poison consumed as per this present study and the same results were observed in the various other studies. ${ }^{8,10,17}$ While Aluminium phosphide was most commonly used poison as per studies were done by Gargi $\mathrm{J},{ }^{9}$ Garg $\mathrm{V}^{18}$ and Patel NS. ${ }^{19}$

Time of poisoning was in the evening between $6 \mathrm{pm}-12 \mathrm{am}$ in $37.50 \%$ of cases. This may be because of whole day frustrations, results of examinations and family fights. Similar results were obtained in various other studies. ${ }^{8,10,20}$ Study done by Guntheti $\mathrm{BK}^{14}$ and Dash SK, ${ }^{21}$ daytime i.e. 6am-6pm recorded in the maximum number of cases.

In the present study, $43.33 \%$ of cases had blood pressure towards the lower side at the time of admission in the hospital. Similar results were observed by Vijayanath $\mathrm{V}^{22}$ and Khurana $\mathrm{P}^{23}$

In the present study majority of the poisoning cases were suicidal $(80 \%)$ in nature of which $47.50 \%$ were males and $32.50 \%$ were females. Similar results were observed in other studies. ${ }^{8,9,18,22}$

Patients who got medical attention within 6 hours of consumption of poisons resulted in the better outcome. The same result was observed in many other studies. ${ }^{11,14,24,25}$

\section{Conclusion}

Due to easy availability of insecticides, pesticides and household poisons; there is more exposure accidently or intentionally, which creates a huge burden on hospitals. The government, WHO, NGO and other organizations have to make strict rules or to ban highly toxic chemicals. Farmers and workers of chemical factories must be trained time to time by organizing camps. In digital India, there must be free mobile apps by the Government where farmers can easily get the answers of their queries. There is an urgent need to establish poison control centre in every state according to the trends of poisoning in that area.

\section{References}

1. Harish D, Chavali KH, Singh A, Kumar A. Recent advances in the management of poisoning cases. Journal of Indian Academy of Forensic Medicine. 2011;33(1):748.

2. Wujastyk D. The Roots of Ayurveda: Selections from Sanskrit Medical Writings. ISBN 0-14-044824-1. p. 144.

3. Carlsten A, Waren M, Allebeck P. Suicides by drug poisoning among the elderly in Sweden 1969-1996. Social Psychiatry and Psychiatric Epidemiology. 1999;34:609-14.

4. Preda A, MacLean RW, Mazure CM, Bowers MB. Antidepressant- associated mania and psychosis resulting in psychiatric admissions. J Clin Psychiatry. 2001;62(1):30-3. 
5. Gangal R, Haroon A. Profile of acute poisoning in paediatric age in district Moradabad: hospital based study. J Indian Academy of Forensic Medicine. 2015; 37 (2):155-9.

6. Gupta P, Honnungar RS, Puja SS. Trend of male poisoning at north Karnataka from 2008-2013. J Indian Academy of Forensic Medicine. 2015; 37 (3):278-80.

7. Rao CHS, Venkateswarlu V, Surender T, Eddleston M and Buckley NA.Pesticide Poisoning in South India Opportunities for Prevention and Improved Medical Management. Trop Med Int. Health. 2005;10(6):581-588.

8. Gopal BK, Viswakanth B, Shruti P, Varma RK. A retrospective analysis of suicidal poisoning deaths in a metropolitan city of South India. Journal of Indian Academy of Forensic Medicine. 2015; 37 (2): 140-43.

9. Gargi J, Rai H, Chanana A, Rai G, Sharma G, Bagga IJS. Current trends of poisoning- A hospital profile. Journal of Punjab Academy of Forensic Medicine and Toxicology. 2003;3:41-5.

10. Haloi M, Haloi MD, Patowary A. Death due to poisoning in District of Kamrup, Assam- A medico-legal study. Journal of Indian Academy of Forensic Medicine. 2013;35(1):17-20.

11. Naik SB, Mohan AM, Shetty D. Profile of acute poisoning at Moodabidri, Karnataka (South India): Retrospective survey. Journal of the Indian society of toxicology. 2011;7(1):32-7.

12. Jayachandran M, Chief T, Richard GM, Askar SI, Gope R. A study on contemporary trends of acute fatal poisoning of pediatric age group in rural tertiary care hospital. Medico-legal update. 2016;16(2):86-90.

13. Barman DD, Nair VK, Karnaboopathy GR. Study of trend of poisoning in a tertiary care hospital in Chidambaram, Tamilnadu. Journal of Indian Academy of Forensic Medicine. 2017;39(1):20-4.

14. Guntheti BK, Singh UP. The pattern of poisoning in Khammam. Journal of Indian Academy of Forensic Medicine. 2011;33(4):296-300.

15. ReddyA, Aridoss S, Kagne RN, Balaraman R, Kumaran M. Profile of acute poisoning fatalities at Puducherry, Southern India. Medico-legal update. 2016;16 (1)185-90.

16. Maled V. Demographic profile of accidental poisoning in rural India. Journal of the Indian society of toxicology. 2016;12(1):18-21.

17. Gangal R, Haroon A. Profile of acute poisoning in paediatric age in district Moradabad: A hospital based study. Journal of Indian Academy of Forensic Medicine. 2015;37(2):155-9.

18. Garg V, Verma SK. Trends of poisoning in rural area of south-west, Punjab. Journal of Indian Academy of Forensic Medicine. 2010;3(3):189-93.

19. Patel NS, Srivastava AK, Kumar A, Kumar JKV, Nandwani S. Trends of poisoning in western Utter Pradesh a clinico-pathological study. Journal of Indian Academy of Forensic Medicine. 2014;36(2):142-5.

20. Tandle RM, Kadu SS, Deshpande VL, Waje DR. Study of acute poisoning cases at rural tertiary care hospital in Ahmednagar, Maharastra. Medico-legal update. 2016;16(2):42-5.

21. Dash SK, Raju AS, Mohanty MK, Patnaik KK, Mohanty S. Socio-demographic profile of poisoning cases. Journal of Indian Academy of Forensic Medicine. 2005;27(3):133-8.

22. Vijaynath V, Anita MR, Raju GM, Vijayamahantesh SN. Forensic view on aluminium phosphide poisoning. Journal of Indian Academy of Forensic Medicine. 2011;33(4):289-91.
23. Khurana P, Dalal JS, Multani AS, Tejpal HR. The study of aluminium phosphide poisoning in a tertiary care hospital, Amritsar. Journal of Indian Academy of Forensic Medicine. 2011;33(4):330-4.

24. Saxena V, Atal DK, Das S. Retrospective analysis of pattern of poisoning in Uttarakhand. Journal of Indian Academy of Forensic Medicine. 2014;36 (3):230-3.

25. Panda BB, Hansda MK, Mishra K, Samantsinghar P. Study of poisoning cases in an Indian tertiary care teaching hospital. Journal of Indian Academy of Forensic Medicine. 2015;37(2):165-8.

26. Suryakantha AH. Community Medicine with Recent Advances. $3^{\text {rd }}$ ed. New Delhi, Jitendar P Vij. Jaypee Brothers Medical Publishers (P) Ltd; 2014:620-1. 